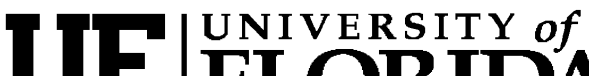 FLORIDA \\ IFAS Extension
}

\section{Reclaimed Water and Florida's Water Reuse Program ${ }^{1}$}

\section{Christopher J. Martinez and Mark W. Clark ${ }^{2}$ Introduction}

Reclaimed water is water from municipal wastewater treatment plants that has been treated to levels that allow safe use for designated purposes. "Water reuse" is the term used to describe the application of reclaimed water for beneficial purposes. Approximately 663 million gallons of reclaimed water is used every day in Florida (Florida Department of Environmental Protection, 2009). Florida is a recognized leader in the use of reclaimed water and its reuse program was the first recipient of the United States Environmental Protection Agency Water Efficiency Leader Award in 2006.

Encouraging and promoting reuse in Florida is a state objective for conserving freshwater supplies and preserving rivers, streams, lakes, and aquifers.

\section{Why reuse water?}

While Florida receives a large amount of rainfall compared to other states, approximately half of the rainfall occurs over the four months from June to September, and the remaining half falls between the other eight months of the year. Periodic droughts combined with increased demand for fresh, clean surface and groundwater for public consumption have resulted in periodic and prolonged water shortages.
Florida's population is expected to increase from 16 million in 1995 to 22 million by the year 2020 and freshwater needs are expected to grow from 8.2 to 9.1 billion gallons per day (Florida Council of 100, 2003). Currently a large percentage (40-60\%) of potable water (drinking quality water) is used for non-potable needs such as landscape irrigation. Conservation measures such as irrigating with reclaimed water is one way to reduce the use of existing potable water supplies.

Reusing water has several environmental benefits:

- Reduced groundwater withdrawals;

- Reduced need for new drinking water supplies such as new surface water withdrawals or desalination plants;

- Reduced need for new drinking water infrastructure such as storage reservoirs, pipelines and water treatment plants; and

- Improved water quality of the natural environment by reducing the amount of nutrients that are discharged directly to surface and groundwaters.

1. This document is AE448, one of a series of the Agricultural and Biological Engineering Department, Florida Cooperative Extension Service, Institute of Food and Agricultural Sciences, University of Florida. Original publication date July 2009. Visit the EDIS Web Site at http://edis.ifas.ufl.edu.

2. Christpher J. Martinez, assistant professor, Department of Agricultural and Biological Engineering; Mark W. Clark, assistant professor, Department of Soil and Water Science; Florida Cooperative Extension Service, Institute of Food and Agricultural Sciences, University of Florida, Gainesville, FL 32611.

The Institute of Food and Agricultural Sciences (IFAS) is an Equal Opportunity Institution authorized to provide research, educational information and other services only to individuals and institutions that function with non-discrimination with respect to race, creed, color, religion, age, disability, sex, sexual orientation, marital status, national origin, political opinions or affiliations. U.S. Department of Agriculture, Cooperative Extension Service, University of Florida, IFAS, Florida A. \& M. University Cooperative Extension Program, and Boards of County Commissioners Cooperating. Millie Ferrer, Interim Dean. 
Reusing water helps conserve drinking water supplies by replacing the use of drinking quality water for non-drinking water purposes. Opportunities for reusing reclaimed water are numerous and include irrigation, industrial cooling water, groundwater recharge, and preventing salt water intrusion in coastal groundwater aquifers. In coastal areas, where the majority of the population of Florida lives, groundwater is vulnerable to saltwater intrusion caused by over-pumping of groundwater. Reclaimed water can be used to recharge groundwater to form a barrier between salt and fresh groundwater. The idea behind water reuse is simple: use the right water for the right use.

Reusing water helps reduce environmental degradation of lakes, rivers, streams and coastal waters by reducing the amount of nutrients that are directly discharged to natural systems, which has been the traditional wastewater disposal method. These same nutrients can be beneficial when applied to irrigated landscapes and can reduce the need for additional fertilizers (King et al., 2000; Lazarova and Asano, 2005; U.S. EPA, 2004). However, landscape irrigation with reclaimed water must be managed carefully to reduce the potential for eutrophication of water bodies. Eutrophication is the process where enhanced plant growth occurs in response to excess nutrients entering a water body and can potentially deplete dissolved oxygen. More information on using reclaimed water for landscape irrigation can be found in Using Reclaimed Water for Landscape Irrigation at http://edis.ifas.ufl.edu/AE449

Traditionally viewed as a waste to be disposed of, reclaimed water is now viewed as a valuable resource by conserving water as well as for the supply of nutrients it contains.

\section{How is reclaimed water used in Florida?}

In Florida, reclaimed water is used in a variety of ways with the largest amount used for irrigating public access areas (Figure 1). Public access areas include residential areas, golf courses, athletic fields, parks, etc. Following public access areas, the next largest uses are groundwater recharge and industrial uses such as cooling water in power plants. Most of the reclaimed water used for agricultural irrigation is used to grow feed, fiber, or other crops that are not for direct human consumption. Reclaimed water can be used to grow crops for human consumption in Florida, but it must meet the same stringent treatment and disinfection requirements as water for public access area use and it is not allowed to come in direct contact with crops that will not be peeled, skinned, cooked, or thermally processed. The treatment and disinfection requirements for different uses of reclaimed water are discussed further below.

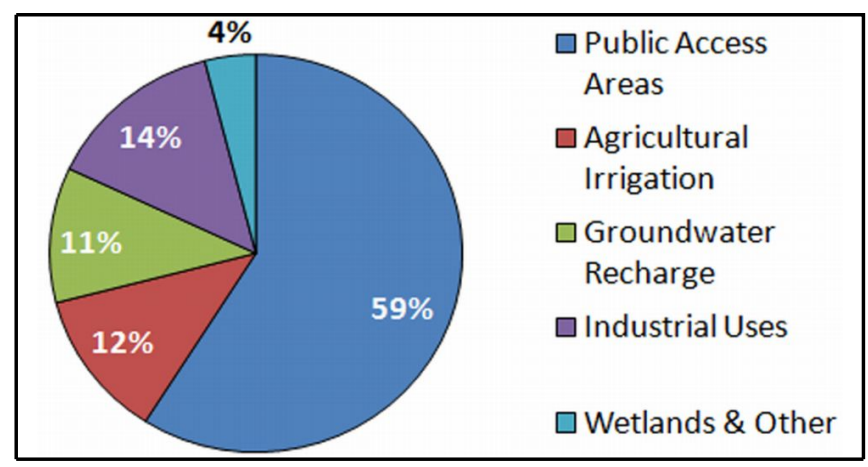

Figure 1. Reuse activities in Florida (adapted from FDEP, 2009)

\section{What is reclaimed water and how is it produced?}

Reclaimed water is treated wastewater that has received, at a minimum, secondary-level treatment and basic disinfection at a wastewater treatment facility. There are three stages of wastewater treatment: primary, secondary, and advanced (sometimes called tertiary treatment) (Figure 2). During primary treatment, suspended solids are removed by screening and settling. The water is then subjected to secondary treatment where biological decomposition reduces complex organic material into simpler forms. The water is then separated from any remaining organic material and then either disinfected (often by chlorination) and directly discharged, reused, or subjected to advanced treatment. Advanced treatment facilities further remove solids, organic material, nutrients, or other chemicals using physical, chemical, or biological processes. After advanced treatment the water is then disinfected before being discharged (typically to rivers, lakes, or coastal waters) or reused. The main difference 
between reclaimed water that has received secondary vs. tertiary treatment is the level of nutrients that remain in the water. Tertiary treated water typically has $25 \%$ of the nitrogen and phosphorus contained in secondary treated reclaimed water (Tchobanoglous et al., 2003; Asano et al., 2007). However, the nutrient content of reclaimed water from a particular treatment plant will depend on the treatment processes used.

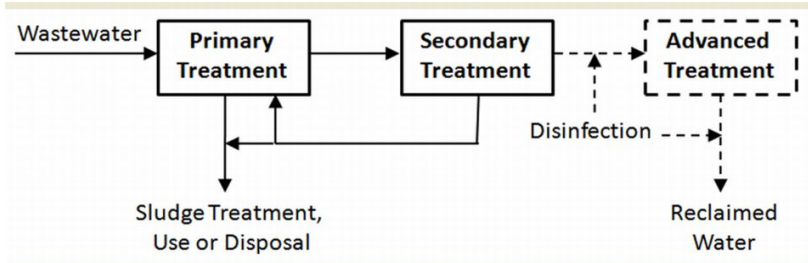

Figure 2. The wastewater treatment process. Some or all of the reclaimed water can be reused. Advanced treatment is an optional step in the treatment process. Disinfection occurs after advanced treatment in facilities that use this step, otherwise disinfection occurs after secondary treatment.

\section{What are the treatment requirements for using reclaimed water?}

There are no federal regulations governing the use of reclaimed water, but the U.S. Environmental Protection Agency has established guidelines to encourage states to develop reuse programs (U.S. EPA, 2004). Depending on how reclaimed water is to be used in Florida, there are specific treatment requirements. These requirements, outlined here, are contained within Chapter 62-610 of the Florida Administrative Code (FAC) and can be found on the Web site of the Florida Department of Environmental Protection

(

http://www.dep.state.fl.us/legal/rules/wastewater/62610.pdf). Table 1 shows the different types of reuse systems in Florida and a brief description of the treatment and disinfection requirements for each. For a complete description of the treatment and disinfection requirements for each type of application, the reader is referred to Chapter 62-610 via the above Web link.

More information on Florida's reuse program can be found on the Florida Department of
Environmental Protection Reuse Program Web site (http://www.dep.state.fl.us/water/reuse/). For information on Water Conserv II, a cooperative water reclaimation program used for irrigating over 3,200 acres of crops (primarily citrus) in Florida see Parsons (2007)

http://www.crec.ifas.ufl.edu/academics/faculty/ parsons/PDF/MayParsons.pdf. For information on using reclaimed water for landscape irrigation in Florida see Using Reclaimed Water for Landscape Irrigation at http://edis.ifas.ufl.edu/AE449.

\section{References}

Asano, T., Burton, F.L., Leverenz, H.L., Tsuchihashi, R., and G. Tchobanoglous. 2007. Water Reuse: Issues, Technologies, and Applications. McGraw Hill, New York, NY.

Florida Department of Environmental Protection (FDEP). 2009. 2007 Reuse Inventory. Florida Department of Environmental Protection Reuse Program.

http://www.dep.state.fl.us/water/reuse/docs/inventory/ ReuseInventory07.pdf (last accessed 7/7/09)

Florida Council of 100. 2003. Improving Florida's Water Supply Management Structure: Ensuring and Sustaining Environmentally Sound Water Supplies and Resources to Meet Current and Future Needs. Florida Council of 100. http://www.fc100.org/reports/waterreportfinal.pdf (last accessed 4/16/2009)

Florida Department of Environmental Protection (FDEP). 2007. Reuse of Reclaimed Water and Land Application. Rule 62-610 Florida Administrative Code.

http://www.dep.state.fl.us/legal/rules/wastewater/62610.pdf (last accessed 2/18/09)

King, K.W., Balogh, J.C. and R.D. Harmel. 2000. Feeding turf with wastewater. Golf Course Management 68: 59-62. http://archive.lib.msu.edu/tic/gcman/article/ 2000jan59.pdf (last accessed 3/9/09)

Lazarova, V. and T. Asano. 2005. Challenges of sustainable irrigation with recycled water. pp 1-30. In: Lazarova, V. and A. Bahri (eds). Water Reuse for 
Irrigation: Agriculture, Landscapes, and Turf

Grasses. CRC Press, Boca Raton, FL.

Parsons, L.R. 2007. Reclaiming a Resource.

Florida Grower, p 40, May 2007.

http://www.crec.ifas.ufl.edu/academics/faculty/

parsons/PDF/MayParsons.pdf

Tchobanoglous, G., Burton, F.L., and H.D.

Stensel. 2003. Wastewater Engineering: Treatment

and Reuse. Fourth Edition. McGraw Hill, New York, NY.

United States Environmental Protection Agency (U.S. EPA). 2004. Guidelines for Water Reuse. EPA 645-R-04-108. United States Environmental Protection Agency, Washington, D.C. http://www.epa.gov/ord/NRMRL/pubs/625r04108/ 625r04108.pdf (last accessed 2/18/09) 
Table 1. Reuse system types in Florida

\begin{tabular}{|c|c|c|c|}
\hline Reuse System Type & Reuse Activities & $\begin{array}{l}\text { Part in } \\
\text { Chapter } \\
62-610 \\
\end{array}$ & $\begin{array}{l}\text { Treatment and Disinfection } \\
\text { Requirements }^{\mathrm{a}}\end{array}$ \\
\hline $\begin{array}{l}\text { Slow-rate land } \\
\text { application systems; } \\
\text { restricted public access }\end{array}$ & $\begin{array}{l}\text { Irrigation of pastures, trees, } \\
\text { feed, fodder, fiber, or seed crops }\end{array}$ & II & $\begin{array}{l}\text { Secondary treatment and basic } \\
\text { disinfection }\end{array}$ \\
\hline $\begin{array}{l}\text { Slow-rate land } \\
\text { application systems; } \\
\text { public access areas, } \\
\text { residential irrigation, and } \\
\text { edible crops }\end{array}$ & $\begin{array}{l}\text { Residential, golf course, and } \\
\text { other landscape irrigation } \\
\text { Toilet flushing } \\
\text { Fire protection } \\
\text { Dust control } \\
\text { Aesthetic features (ponds and } \\
\text { fountains) } \\
\text { Irrigation of edible crops (direct } \\
\text { contact only with crops that will } \\
\text { be peeled, skinned, cooked, or } \\
\text { thermally processed) }\end{array}$ & III & $\begin{array}{l}\text { Secondary treatment, filtration, } \\
\text { and high-level disinfection }\end{array}$ \\
\hline $\begin{array}{l}\text { Rapid-rate land } \\
\text { application systems }\end{array}$ & $\begin{array}{l}\text { Rapid Infiltration Basins (RIBs) } \\
\text { Absorption Fields }\end{array}$ & IV & $\begin{array}{l}\text { Secondary treatment, basic } \\
\text { disinfection, }<12 \mathrm{mg} / \mathrm{L} \mathrm{NO}-\mathrm{N}^{\mathrm{b}}\end{array}$ \\
\hline $\begin{array}{l}\text { Groundwater recharge } \\
\text { and indirect potable } \\
\text { reuse }\end{array}$ & $\begin{array}{l}\text { Salinity barriers } \\
\text { Augmentation of surface waters }\end{array}$ & $\mathrm{V}$ & $\begin{array}{l}\text { Principal treatment and } \\
\text { disinfection or full treatment } \\
\text { and disinfection (depending on } \\
\text { use) }\end{array}$ \\
\hline Overland flow systems & & $\mathrm{VI}$ & Low-level disinfection \\
\hline $\begin{array}{l}\text { Industrial uses of } \\
\text { reclaimed water }\end{array}$ & $\begin{array}{l}\text { Cooling water } \\
\text { Wash water } \\
\text { Process water (not to include } \\
\text { food processing for human } \\
\text { consumption) }\end{array}$ & VII & $\begin{array}{l}\text { Secondary treatment and basic } \\
\text { disinfection (additional } \\
\text { treatment may be needed to } \\
\text { meet needs of a particular } \\
\text { application) }\end{array}$ \\
\hline \multicolumn{4}{|c|}{$\begin{array}{l}\text { a The reader is referred to Chapter 62-610 F.A.C. for specific treatment and disinfection requirements. } \\
{ }^{b} \text { Nitrate as nitrogen. } \\
{ }^{c} \text { The reader is referred to Chapter } 61-610 \text { F.A.C. for specific treatment and disinfection descriptions. }\end{array}$} \\
\hline
\end{tabular}

